\title{
Nature of Genetic Variability for Yield and Drought Tolerance Related Physiological Traits in Clusterbean [Cyamopsis tetragonoloba $(\mathbf{L}$.$) ]$
}

\author{
Vishal L. Modi and S. C. Sharma* \\ Department of Genetics and Plant Breeding, C.P. College of Agriculture, Sardarkrushinagar \\ Dantiwada Agricultural University, Sardarkrushinagr, Guarat, India \\ *Corresponding author
}

\section{A B S T R A C T}

Keywords

Genetic variability, Clusterbean (Cyamopsis tetragonoloba $(\mathrm{L}$.$) ,$ heritability, Genetic advance

Article Info

Accepted:

18 December 2020

Available Online:

10 January 2021
The present investigation was conducted to elicit information on different genetic variability parameters for 11 morphological and 6 drought tolerance related physiological traits viz., days to $50 \%$ flowering, days to maturity, plant height, number of branches per plant, number of pods per plant, pod length, seeds per pod, 100-seed weight, biological yield per plant, grain yield per plant, harvest index, relative water content, leaf area per plant, chlorophyll content, leaf thickness, seedling vigour index and germination stress index in different types of clusterbean genotypes. Mean squares due to genotypes revealed a wide range of variability and significant differences among all genotypes for all the characters under study. The range of variability was maximum for leaf area per plant followed by seedling vigour index, germination stress index, chlorophyll content and plant height. High genetic gain along with high heritability and moderate genotypic coefficient of variation was recorded for germination stress index, leaf area per plant and seedling vigour index, while high genetic gain with moderate heritability and genotypic coefficient of variation was recorded for number of pods per plant, grain yield per plant and biological yield per plant.

\section{Introduction}

Clusterbean (Cyamopsis tetragonoloba (L.) Taub.) commonly known as guar has achieved status of an industrial crop due to its water soluble natural polymer i.e. galactomannan content (gum). Average productivity of clusterbean is very low as the crop is confined to rainfed farming in poor fertile soils and drought prone areas of arid and semi arid regions. Although, clusterbean is an important drought tolerant crop but very meager information is available on the physiology of this crop. Therefore, it is of paramount importance to study the genetics of drought tolerance related traits and develop tolerant genotypes based on sound physiological mechanisms in clusterbean.

With increasing constraint in the production of guar, breeders look for new and diverse germplasm with specific traits of altered growth habit to enhance crop productivity). Identification of new germplasm possessing 
unbranched, erect, all node cluster bearing ability, photo-in sensitiveness and determinate growth habit will allow clusterbean to be developed as a modern crop that is well suited to intensive agronomic management conditions.

To make a breeding programme successful, the breeder requires plant material with large genetic variability because effective selection is dependent on the existence of genetic amount of variability. Information about yield and drought related physiological parameters in clusterbean can be obtained through coefficient of variation, heritability and genetic gain. This would help the breeder in developing and formulating selection programme for genetic improvement in crop plants.

\section{Materials and Methods}

The experimental material consisted of 26 genotypes selected on the basis of spread and growth habit of clusterbean (8 single stem, 8 branched, 8 dwarf +2 check i.e. GG-1 and GG-2) of clusterbean grown in randomised block design (RBD) with 3 replications at Centre of Excellence for Research on Pulses, Sardarkrushinagar Dantiwada Agricultural University, Sardarkrushinagar, Gujarat. Each genotype was accommodated in 6 rows plot of $4 \mathrm{~m}$ length with $45 \mathrm{~cm}$ inter row and $10 \mathrm{~cm}$ plant to plant distance. These materials were planted in to elicit information on 11 morphological and 6 drought tolerance related physiological traits viz., days to $50 \%$ flowering, days to maturity, plant height $(\mathrm{cm})$, number of branches per plant, number of pods per plant, pod length $(\mathrm{cm})$, seeds per pod, 100-seed weight (g), biological yield per plant $(\mathrm{g})$, grain yield per plant $(\mathrm{g})$, harvest index $(\%)$, relative water content, leaf area per plant $\left(\mathrm{cm}^{2}\right)$, chlorophyll content, leaf thickness $(\mathrm{mm})$, seedling vigour index and germination stress index. The collected data from five randomly selected competitive plants from each plot in each replication were subjected to analysis of variance (Panse and Sukhatme, 1985), genotypic and phenotypic coefficient of variation (Burton, 1952), heritability (Allard, 1960) genetic advance and genetic gain (Johnson et al., 1955).

\section{Results and Discussion}

Mean squares due to genotypes revealed a wide range of variability and significant differences among all genotypes for all the characters under study. This naturally suggests that there is an ample scope for improving these characters provided the material is subjected to judicious selection pressure (Table 1). The range of variability was maximum for leaf area per plant followed by seedling vigour index, germination stress index, chlorophyll content and plant height. The genotypic variance followed the trend of phenotypic variance and was greater than environmental variance for all the characters under study indicating that phenotypic variability may be considered as reliable measure of genotypic variability (Table 2 ). In general, estimate of phenotypic coefficient of variance (PCV) was higher than their corresponding genotypic coefficient of variance $(\mathrm{GCV})$. This might be due to effect of environment in the expression of the characters (Table 3). The least differences between GCV and PCV were observed for characters viz., pod length followed by plant height, leaf thickness, biological yield per plant, seeds per pod, number of pods per plant, relative water content, chlorophyll content, grain yield per plant, 100-seed weight, days to $50 \%$ flowering, leaf area per plant, days to maturity, number of branches per plant, germination stress index and seedling vigour index indicating that genetic factors are predominantly responsible for these characters. However, the difference between GCV and PCV was higher for 
harvest index indicating environmental influence on this character.

The magnitude of GCV and PCV was highest for number of branches of plant, while moderate coefficient of variation was observed for number of pods per plant followed by grain yield per plant, leaf area per plant, germination stress index, biological yield per plant and seedling vigour index. It indicated greater scope for selection to improve upon these characters. On the other hand, the characters plant height, chlorophyll content, leaf thickness, 100-seed weight, pod length, relative water content, seeds per pod, days to $50 \%$ flowering and days to maturity showed low GCV and PCV indicating that these characters were highly influenced by the environmental fluctuation and having low genetic variations (Table 3). High to moderate values for one or more yield and physiological characters in clusterbean and other crops are also reported by Chaudhary and Shrimali (2006), Prasad et al., (2006), Birdar et al., (2007), John et al., (2008a, 2008b) and Arora et al., (2011).

Table.1 Analysis of variance (ANOVA) showing mean sum of squares of different characters in clusterbean

\begin{tabular}{|c|c|c|c|c|}
\hline $\begin{array}{l}\text { Sr. } \\
\text { No. }\end{array}$ & Source & $\begin{array}{l}\text { Replications } \\
\quad(\text { d.f. }=2)\end{array}$ & $\begin{array}{c}\text { Genotypes } \\
(\text { d.f. = 25) }\end{array}$ & $\begin{array}{c}\text { Error } \\
(\text { d.f. }=\mathbf{5 0})\end{array}$ \\
\hline 1. & Days to $50 \%$ flowering & 0.13 & $4.03 * *$ & 1.45 \\
\hline 2. & Days to maturity & 7.95 & $6.17 *$ & 3.25 \\
\hline 3. & Plant height $(\mathrm{cm})$ & 0.77 & $132.11 * *$ & 31.56 \\
\hline 4. & Number of branches per plant & 0.32 & $12.27 * *$ & 0.14 \\
\hline 5. & Number of pods per plant & 16.02 & $218.62 * *$ & 25.12 \\
\hline 6. & Pod length $(\mathrm{cm})$ & 0.12 & $0.40 * *$ & 0.16 \\
\hline 7. & Seeds per pod & 0.25 & $0.34 *$ & 0.19 \\
\hline 8. & 100- Seed weight (g) & 0.02 & $0.19 * *$ & 0.02 \\
\hline 9. & Biological yield per plant (g) & 3.32 & $36.50 * *$ & 5.15 \\
\hline 10. & Grain yield per plant (g) & 0.32 & $4.04 * *$ & 0.44 \\
\hline 11. & Harvest index (\%) & 0.30 & $47.25 *$ & 26.02 \\
\hline 12. & Relative water content (\%) & 68.53 & $50.76^{*}$ & 25.51 \\
\hline 13. & Lea area per plant $\left(\mathrm{cm}^{2}\right)$ & 196.00 & $195346.78 * *$ & 10130.29 \\
\hline 14. & Chlorophyll content & 11.47 & $386.75^{* *}$ & 87.41 \\
\hline 15. & Leaf thickness (mm) & 0.0020 & $0.0034 * *$ & 0.0010 \\
\hline 16. & Seedling vigour index & 3578.00 & $69892.90 * *$ & 3040.75 \\
\hline 17. & Germination stress index & 4.69 & $642.68 * *$ & 27.03 \\
\hline
\end{tabular}

$*$, ** Significant at 0.05 and 0.01 per cent levels, respectively 
Table.2 Range, Mean and components of variance for different characters in clusterbean

\begin{tabular}{|c|c|c|c|c|c|c|c|c|}
\hline \multirow[t]{2}{*}{ Sr. No. } & \multirow[t]{2}{*}{ Character } & \multirow[t]{2}{*}{ Range } & \multirow[t]{2}{*}{ Mean \pm S.E. } & \multirow[t]{2}{*}{ C.D. } & \multirow[t]{2}{*}{ C.V.\% } & \multicolumn{3}{|c|}{ Variance components } \\
\hline & & & & & & Vp & $\mathbf{V g}$ & Ve \\
\hline 1. & Days to $50 \%$ flowering & $36.00-40.67$ & $38.18 \pm 0.98$ & 1.97 & 3.15 & 2.31 & 0.86 & 1.45 \\
\hline 2. & Days to maturity & $68.67-73.33$ & $70.61 \pm 1.47$ & 2.95 & 2.55 & 4.22 & 0.97 & 3.25 \\
\hline 3. & Plant height $(\mathrm{cm})$ & $39.00-67.67$ & $53.95 \pm 4.59$ & 9.21 & 10.41 & 65.08 & 33.52 & 31.56 \\
\hline 4. & $\begin{array}{c}\text { Number of branches per } \\
\text { plant }\end{array}$ & $0.00-5.33$ & $2.65 \pm 0.30$ & 0.61 & 14.11 & 4.18 & 4.04 & 0.14 \\
\hline 5. & Number of pods per plant & $21.87-50.90$ & $37.54 \pm 4.09$ & 8.22 & 13.35 & 89.62 & 64.50 & 25.12 \\
\hline 6. & Pod length $(\mathrm{cm})$ & $4.27-5.93$ & $4.89 \pm 0.33$ & 0.66 & 8.18 & 0.24 & 0.08 & 0.16 \\
\hline 7. & Seeds per pod & $6.20-7.90$ & $6.88 \pm 0.36$ & 0.72 & 6.37 & 0.24 & 0.05 & 0.19 \\
\hline 8. & 100 - Seed weight $(\mathrm{g})$ & $2.44-3.42$ & $3.12 \pm 0.13$ & 0.26 & 5.11 & 0.08 & 0.06 & 0.02 \\
\hline 9. & $\begin{array}{l}\text { Biological yield per plant } \\
(\mathrm{g})\end{array}$ & $10.56-25.71$ & $17.68 \pm 1.85$ & 3.72 & 12.83 & 15.60 & 10.45 & 5.15 \\
\hline 10. & Grain yield per plant (g) & $3.19-7.55$ & $5.59 \pm 0.54$ & 1.09 & 11.85 & 1.64 & 1.20 & 0.44 \\
\hline 11. & Harvest index (\%) & $22.56-38.27$ & $32.05 \pm 4.16$ & 8.37 & 15.92 & 33.10 & 7.08 & 26.02 \\
\hline 12. & Relative water content $(\%)$ & $72.29-87.17$ & $79.16 \pm 4.12$ & 8.28 & 6.38 & 33.93 & 8.42 & 25.51 \\
\hline 13. & Lea area per plant $\left(\mathrm{cm}^{2}\right)$ & $810-1696$ & $1272.78 \pm 82.18$ & 165.07 & 7.91 & 71869.12 & 61738.83 & 10130.3 \\
\hline 14. & Chlorophyll content & $91.58-132.77$ & $110.06 \pm 7.63$ & 15.33 & 8.50 & 187.19 & 99.78 & 87.41 \\
\hline 15. & Leaf thickness (mm) & $0.29-0.44$ & $0.34 \pm 0.03$ & 0.05 & 9.37 & 0.0018 & 0.0008 & 0.0010 \\
\hline 16. & Seedling vigour index & $701-1320$ & $894.90 \pm 45.02$ & 90.40 & 6.16 & 25324.80 & 22284.05 & 3040.75 \\
\hline 17. & Germination stress index & $52.00-94.33$ & $74.28 \pm 4.24$ & 8.518 & 7.00 & 232.25 & 205.22 & 27.03 \\
\hline
\end{tabular}

Table.3 The estimates of genotypic coefficients of variation (GCV), phenotypic coefficients of variation (PCV), heritability $\left(\mathrm{h}^{2} \mathrm{~b} \%\right)$, expected genetic advance (GA) and genetic gain (GG) for various characters in clusterbean

\begin{tabular}{|c|c|c|c|c|c|c|}
\hline Sr. No. & Character & GCV & PCV & $\mathbf{h}^{2} \mathbf{b}(\%)$ & GA & GG \\
\hline 1. & Days to $50 \%$ flowering & 2.43 & 3.98 & 37.4 & 1.17 & 3.06 \\
\hline 2. & Days to maturity & 1.40 & 2.91 & 23.1 & 0.98 & 1.39 \\
\hline 3. & Plant height $(\mathrm{cm})$ & 10.73 & 14.95 & 51.5 & 8.56 & 15.87 \\
\hline 4. & Number of branches per plant & 75.75 & 77.05 & 96.6 & 4.07 & 15.30 \\
\hline 5. & Number of pods per plant & 21.39 & 25.21 & 72.0 & 14.03 & 37.37 \\
\hline 6. & Pod length $(\mathrm{cm})$ & 5.77 & 10.01 & 33.2 & 0.34 & 6.95 \\
\hline 7. & Seeds per pod & 3.21 & 7.13 & 20.2 & 0.20 & 2.91 \\
\hline 8. & 100- Seed weight $(\mathrm{g})$ & 7.44 & 9.03 & 67.9 & 0.39 & 12.50 \\
\hline 9. & Biological yield per plant (g) & 18.28 & 22.34 & 67.0 & 5.45 & 30.83 \\
\hline 10. & Grain yield per plant $(\mathrm{g})$ & 19.61 & 22.91 & 73.2 & 1.93 & 34.53 \\
\hline 11. & Harvest index (\%) & 8.30 & 17.95 & 21.4 & 2.53 & 7.89 \\
\hline 12. & Relative water content (\%) & 3.66 & 7.36 & 24.8 & 2.98 & 3.76 \\
\hline 13. & Lea area per plant $\left(\mathrm{cm}^{2}\right)$ & 19.52 & 21.06 & 85.9 & 47.40 & 37.27 \\
\hline 14. & Chlorophyll content & 9.08 & 12.43 & 53.3 & 15.02 & 13.65 \\
\hline 15. & Leaf thickness (mm) & 8.14 & 12.36 & 43.4 & 0.04 & 11.76 \\
\hline 16. & Seedling vigour index & 16.68 & 17.78 & 88.0 & 28.80 & 32.23 \\
\hline 17. & Germination stress index & 19.29 & 20.52 & 88.4 & 27.74 & 37.35 \\
\hline
\end{tabular}


High heritability in broad sense (above 75\%) was recorded for number of branches per plant followed by germination stress index, seedling vigour index and leaf area per plant. This indicated high transmission index for the characters and suggested that a large portion of phenotypic variability was heritable; therefore, selection based on phenotype could be effective. Moderate estimates of heritability (above 50\%) were recorded for grain yield per plant followed by number of pods per plant, 100-seed weight, biological yield per plant, chlorophyll content and plant height. The remaining characters such as leaf thickness, days to $50 \%$ flowering, pod length, relative water content, days to maturity, harvest index and seeds per pod, however, showed low heritability (below 50\%) suggesting greater influence of environment on these traits (Table 3). High to moderate heritability values are also confirmed in clusterbean and other crops for one or more yield and drought related physiological traits with the findings of Buttar et al., (2008), Rai (2010), Saini et al., (2010) and Rai et al., (2012).

Genetic gain was higher for number of pods per plant followed by germination stress index, leaf area per plant, grain yield per plant, seedling vigour index and biological yield per plant, while moderate genetic gain was recorded for plant height followed by number of branches per plant, chlorophyll content, 100-seed weight and leaf thickness.

The remaining traits which showed low value of genetic gain were harvest index, pod length, relative water content, days to $50 \%$ flowering, seeds per pod and days to maturity (Table 3). Similar results of moderate to high genetic gain were also reported for one or more traits in clusterbean and other crops by Jadli et al., (2008), Saini et al., (2010), Nandini et al., (2011) and Rai et al., (2012).
In the present study, in general, genetic gain, heritability and genotypic coefficient of variation exhibited good association with each other. High genetic gain along with high heritability and moderate genotypic coefficient of variation was recorded for germination stress index, leaf area per plant and seedling vigour index, while high genetic gain with moderate heritability and genotypic coefficient of variation was recorded for number of pods per plant, grain yield per plant and biological yield per plant. Branches per plant exhibited moderate genetic gain inspite of having the highest heritability and genotypic coefficient of variation. It appeared that these characters might be exhibiting predominance of additive gene effects. Hence, selection for these traits would be effective for genetic improvement of grain yield along with drought tolerance in clusterbean. Thus, strong evaluation programme is to be taken for exploitation of these characters for high yield along with drought tolerance.

\section{References}

Allard, R. W. (1960). "Principles of plant breeding."John wiley and sons. Inc. New York.

Arora, D., Dhillon, N. P. S. and Sidhu, A. S. (2011). Characterization and evaluation of north Indian clusterbean (Cyamopsis tetragonoloba (L.) Taub.) germplasm collection. Electronic Journal of Plant Breeding, 2(3): 417-421.

Biradar, K. S., Sailmath, P. M. and Ravikumar, R. L. (2007). Genetic variability for seedling vigour, yield and yield components in local germplasm collections of greengram (Vigna radiata (L.) Wilczek). Karnataka J. Agric. Sci., 20(3): 608-609.

Burton, G. W. (1952). Quantitative inheritance in grasses. Proc. $6^{\text {th }}$ Int. Grassid Congr., 1: 227-283.

Buttar, G. S., Brar, K. S. and Singh, S. (2008). 
Genetic architecture of seed yield and its attributing traits in clusterbean (Cyamopsis tetragonoloba (L.) Taub.) grown under semi-arid region of Punjab. Indian J. Agric. Sci., 78(9): 795-797.

Choudhary, A. K. and Shrimali, M. (2006). Quantitative genetic analysis in clusterbean (Cyamopsis tetragonoloba (L.) Taub.) genotypes to assess their suitability for cultivation in summer season. J. Arid Legumes, 3(1): 79-82.

Jadli, S., Singh, J. P., Prasad, R., Bhushan, K. B. and Thapliyal, A. (2008). Potential verses actual seed performance of field pea (Pisum sativum L.). Pantnagar J. Res., 6(2): 270-274.

John, K., Vasanthi, R. P. and Venkateswarlu, O. (2008a). Variability and correlation studies for pod yield and its attributes in $\mathrm{F}_{2}$ generation of six Virginia $\times$ Spanish crosses of groundnut (Arachis hypogaea L.). Legume Res., 31(3):210-213.

John, K., Vasanthi, R. P., Venkateswarlu, O., Muralikrishna, T., and Naidu, P. H. (2008b). Genetic analysis and regression studies for yield and yield attributes in $\mathrm{F}_{2}$ segregating populations of groundnut crosses. Legume Res., 31(1): 26-30.

Johnson, H. W., Robinson, H. P. and Comstock, R. E. (1955). Estimates of genetic and environmental variability in soybean. Agron.J., 47: 314-318.

Nandini, C., Savithramma, D. L. and Babu, N.
N. (2011). Genetic variability analysis for surrogate traits of water use efficiency in $\mathrm{F}_{8}$ recombinant inbred lines of the cross NRCG12568 $\times$ NRCG12326 in groundnut (Arachis hypogaea L.). Electronic Journal of Plant Breeding, 2(4): 555-558.

Panse, V. G. and Sukhatme, P. V. (1985). "Statistical methods for agricultural workers." I.C.A.R., New Delhi.

Prasad, J., Kerketta, V., Prasad, K. D. and Verma, A. K. (2006). Study of genetic parameters under different environment conditions in wheat (Triticum aestivum L.). J. Birsa Agric. Univ., 18(1): 135140.

Rai, P. S., Dharmatti, P. R., Shashidhar, T. R., Patil, R. V. and Patil, B. R. (2012). Genetic variability studies in clusterbean (Cyamopsis tetragonoloba (L.) Taub.). Karnataka J. Agric. Sci., 25(1): 108-111.

Rai, S. P. (2010). Genetic variability studies in clusterbean (Cyamopsis tetragonoloba (L.) Taub.) genotypes. Karnataka J. Agric. Sci., 23(5): 816874.

Saini, D. D., Singh, N. P., Chaudhary, O. P. and Khedar, O. P. (2010). Genetic variability and association of component characters for seed yield in clusterbean (Cyamopsis tetragonoloba (L.) Taub.). J. Arid Legumes, 7(1): 4751.

\section{How to cite this article:}

Vishal L. Modi and Sharma, S. C. 2021. Nature of Genetic Variability for Yield and Drought Tolerance Related Physiological Traits in Clusterbean [Cyamopsis tetragonoloba (L.)]. Int.J.Curr.Microbiol.App.Sci. 10(01): 2867-2872. doi: https://doi.org/10.20546/ijcmas.2021.1001.332 